\title{
Are the Leadership Style and Motivation Influence the Work Performance of Health Center Personnel?
}

\author{
Latty Indriastuti), Endang Sutisna Sulaeman²), Eti Poncorini Pamungkasari²) \\ ${ }^{1)}$ Masters Program in Public Health, Universitas Sebelas Maret \\ ${ }^{2)}$ Faculty of Medicine, Universitas Sebelas Maret
}

\section{ABSTRACT}

Background: The performance of an organization is largely determined by the human resources in it. If the human resources are highly motivated, creative and innovative and are led by leaders who are responsible and have good leadership skills, their performance will be good. This study aims to analyze the influence of the leadership style of the head of the puskesmas and the work motivation of the employees on the performance of the employees of the Puskesmas Ciamis District.

Subjects and Method: This study was conducted using a cross sectional research design. The study was conducted in Ciamis Regency in November - December 2020. Sampling was carried out using random sampling with a total of 200 puskesmas employees in Ciamis Regency. The dependent variable is employee performance. The independent variables include leadership style, work motivation, job satisfaction, education, treatment status, employee status, length of work. Data were collected by questionnaire and analyzed using a multilevel multiple logistic regression.

Results: Good leadership style (b=3.58; 95\% $\mathrm{CI}=1.11$ to $3.80 ; \mathrm{p}=0.000$ ), high work motivation $(b=3.12 ; 95 \% \mathrm{CI}=0.83$ to $3.65 ; \mathrm{p}=0.002)$, have job satisfaction $(\mathrm{b}=2.89 ; 95 \% \mathrm{CI}=0.67$ to
3.53; $\mathrm{p}=0.004)$, higher education $(\mathrm{b}=2.89$; $95 \% \mathrm{CI}=0.60$ to $3.13 ; \mathrm{p}=0.004)$, inpatient care status $(b=2.66 ; 95 \% \mathrm{CI}=0.47$ to $3.12 ; \mathrm{p}=$ o.008), health personnel status $(b=3.68 ; 95 \%$ $\mathrm{CI}=1.46$ to $4.80 ; \mathrm{p}=0.000$ ), and length of service 3 years $(b=2.07 ; 95 \% \mathrm{CI}=0.78$ to $2.76 ; \mathrm{p}=$ o.038) increase the possibility of the performance of puskesmas employees. Variations at the puskesmas level show that there is a contextual effect on employee performance ( ICC $=11.75 \%)$. Conclusion: There is a positive and statistically significant effect on leadership style, work motivation, job satisfaction, education, treatment status, employee status, length of work on the performance of puskesmas employees. Variations at the puskesmas level show that there is a contextual effect on employee performance.

Keywords: employee performance, leadership style, health center,

\section{Correspondence:}

Latty Indriastuti.Masters Program in Public Health, Universitas Sebelas Maret, Surakarta, Jl. Ir. Sutami 36A, Surakarta 57126, Central Java. Email: lattyindria.drg@gmail.com. Mobile: +628999976544.

\section{Cite this as:}

Indriastuti L, Sulaeman ES, Pamungkasari EP (2021). Are the Leadership Style and Motivation Influence the Work Performance of Health Center Personnel?. J Health Policy Manage. 06(03): 168-181. https://doi.org/10.26911/thejhpm.2021.06.03.02.

\section{BACKGROUND}

Improving the quality of human resources aims to change their behavior into behavior that is more capable of carrying out activities in their respective fields, so that organizational goals can be achieved. (Rustilah,
2018). Human resource is a very strategic thing in the organization, meaning that humans play an important role in carrying out activities to achieve organizational goals. For this reason, the existence of human resource in organizations is very 
strong (Aziz, 2016). The performance of an organization is largely determined by the human resources in it. If the human resources have high motivation, are creative and innovative and are led by responsible leaders and have good leadership skills, their performance will be good (Wibowo, 2016).

Performance is basically something that employees do or don't do, employee performance affects how much they contribute to the organization, including the quantity and quality of output, duration of attendance at work and cooperative attitude (Mathis and Jackson, 2002). Performance is the result or level of success of a person as a whole during a certain period in carrying out tasks compared to various possible standards of work results, targets or targets that have been determined and have been mutually agreed upon. Therefore, employee performance will run effectively if it is supported by work motivation (Rivai, 2005).

Motivation is the center of energy for employees in an organization. Motivation greatly affects the morale of employees. It is the spirit of building good relations with stakeholders, enthusiasm in carrying out the job description or the spirit of the employees themselves in improving their lives. Of course, this is done with a sense of comfort, security and happiness, so that in the end it will have an effect on increasing performance and increasing productivity both in quality and quantity (Salbiah and Mahardika, 2017). Motivating is a leadership task, so that employees can do a good job and achieve goals (Sulistiyani, 2008).

According to Maslow (1994 in Sari et al., 2016) employee work motivation will affect the performance that can be achieved only arising from within an employee (internal motivation) or motivation that comes from outside the employee concern- ed (internal motivation). Work motivation in the organization is more directed to provide strength and encouragement in an employee which will affect the implementtation of his duties and responsibilities towards public services. Giving the right motivation to employees will produce optimal performance in serving the public interest (Wahyuni, 2015).

Based on the description, there are other factors that affect individual performance in the organization. That factor is leadership. The role of the leader will be important and needed to meet various needs and also to create a conducive situation. Of the various ways that leaders do in moving their employees to achieve organizational goals, in the end, they must also be able to lead to good performance in their employees. Indirectly, leadership also determines the good or bad performance of its employees. The better a person's leadership towards employees, the higher the employee's performance (Siagian, 2008).

Leadership style is a key factor in the organization. Leadership style is a way for leaders to influence employees to be able to work better in order to achieve organizational goals. An organization will run smoothly in achieving the organizational goals that have been set is strongly influenced by the leadership factor. Therefore, the leader has always been the focus of evaluation as a description of the assessment of the success of an organization (Wahyuni, 2015).

According to the Health Profile of Ciamis Regency in 2017, Ciamis Regency, West Java, has 37 Puskesmas consisting of 20 Nursing Health Centers, 17 Non-Maintenance Health Centers and 85 Supporting Health Centers to serve 1,398,346 residents of Ciamis Regency with a ratio of 1 UPTD Puskesmas in Ciamis Regency for 37,793 
people. The percentage of employees spread across the Ciamis District Health Center in 2017 was $64.4 \%$ of all Ciamis District health employees. However, with a sufficient ratio of Ciamis health center to employees in Ciamis Regency, it does not guarantee the achievement of the health service performance target of Ciamis health center, because the achievement of targets is not optimal in 2017.

Based on the description above, the author is interested in studying empirically by conducting a study entitled "The Influence of the Leadership Style of the Head of the Health Center and Employee Work Motivation on the Performance of the Public Health Center in Ciamis Regency".

\section{SUBJECTS AND METHOD}

\section{Study Design}

This research was conducted using a cross sectional research design. The study was conducted in Ciamis Regency in NovemberDecember 2020 at 25 health centers in Ciamis Regency.

\section{Population and Sample}

In this study, the population studied were puskesmas employees in Ciamis Regency in November-December 2020. Sampling was carried out using a random sampling technique to select employees and puskesmas in Ciamis Regency. The subjects used were 200 subjects from 8 subjects at each level 2 unit (health center).

\section{Study Variables}

The dependent variable is employee performance. Independent variables include: leadership style, work motivation, job satisfaction, education, treatment status, employee status, length of work and level 2 is heath center.

\section{Operational Definition of Variable} Performance is the result of work both in quality and quantity achieved by employees in carrying out their duties in accordance with the responsibilities given to them.

Leadership style is the behavior shown by individuals when influencing the activities of others as perceived by others.

Work motivation is an encouragement to a series of behavioral processes in achieving goals.

Job satisfaction is the feelings and attitudes of employees towards work, work situations and conditions, interactions and employee roles in the work environment related to the needs to be achieved.

Education is the respondent's official education level as a puskesmas employee.

Health Center Care Status is the status as an inpatient puskesmas or a noninpatient puskesmas.

Employee Status is the respondent's status as civil servant, honorarium/ internship.

Length of work is the period of service of the puskesmas respondents at the health center. The measurement scale in the independent variable uses a continuous scale, because for the needs of data analysis it is converted into a dichotomous scale skala.

\section{Instruments}

Data collection techniques were carried out with primary data and secondary data. Primary data were obtained using a questionnaire filled out by the research subjects. Secondary data were obtained from the Ciamis District Health Office in the form of puskesmas employee data and puskesmas data in Ciamis Regency. The instrument used is a questionnaire.

\section{Data Analysis}

Univariate analysis was carried out to see the frequency distribution and characterristics of research subjects, while bivariate analysis used the chi-square test and the calculation of odds ratio (OR) with $95 \%$ confidence level (CI) to study the relationship between the performance of puskes- 
Indriastuti et al./ Leadership Style and Motivation Influence the Work Performance

mas employees and the independent variables. Multivariate analysis was performed using logistic regression through a multilevel approach indicated by the Intra Class Correlation (ICC) value.

\section{Research Ethics}

Research ethics include informed consent, anonymity, confidentiality and ethical clearance. Ethical clearance in this study was carried out at Dr Moewardi Hospital Surakarta and was declared ethically fit based on decree number: 1.404/XII/ HREC/2019.

\section{RESULTS}

\section{Characteristics of study subjects}

Table 1 shows that the measurement of the research subjects which amounted to 200 employees with the characteristics of employee age had a mean value $=38.04$ and $\mathrm{SD}=10.73$ with the lowest age being 20 years and the highest being 58 years.

Table 1. Characteristics of study subjects (continuous data)

\begin{tabular}{cccccc}
\hline Characteristics & N & Mean & SD & Min. & Maks. \\
\hline Age (year) & 200 & 38.04 & 10.73 & 20 & 58 \\
\hline
\end{tabular}

Table 2 shows that most of the research subjects were female, 104 employees (52.0\%) and 96 employees (48.0\%) were male.

\section{Univariate of Analysis}

Univariate analysis on, among others, leadership style, work motivation, job satisfaction, employee performance.

Table 2. Characteristics of research subjects (dichotomous data)

\begin{tabular}{lcc}
\hline Characteristics & N & \% \\
\hline Gender & & \\
Male & 96 & 48.0 \\
Female & 104 & 52.0 \\
\hline
\end{tabular}

Table 3. Univariate analysis (continuous data)

\begin{tabular}{lccccc}
\hline \multicolumn{1}{c}{ Variable } & N & Mean & SD & Min. & Maks. \\
\hline Leadership Style & 200 & 55.35 & 13.55 & 27 & 75 \\
Working Motivation & 200 & 186.63 & 38.40 & 111 & 241 \\
Job Satisfaction & 200 & 15.77 & 5.83 & 4 & 25 \\
Employee Performance & 200 & 27.93 & 7.27 & 10 & 38 \\
\hline
\end{tabular}

Table 4. Univariate analysis (dichotomous data)

\begin{tabular}{lcc}
\hline Variable & $\mathbf{N}$ & $\mathbf{\%}$ \\
\hline Education & & \\
$\quad<$ DIII & 51 & 25.5 \\
$\quad \geq$ DIII & 149 & 74.5 \\
Treatment Status & & \\
$\quad$ Non hospitalization & 54 & 27.0 \\
Non hospitalization & 147 & 73.0 \\
Employee Status & & \\
$\quad$ Intern & 31 & 15.5 \\
$\quad$ Non permanent employee/Civil servant & 169 & 84.5 \\
Duration of Working & & \\
$\quad<3$ years & 44 & 22.0 \\
$\quad \geq 3$ years & 156 & 78.0 \\
\hline
\end{tabular}


Indriastuti et al./ Leadership Style and Motivation Influence the Work Performance

Table 3 shows the measurement of the leadership style variable for the head of the puskesmas has a mean $=55.35$ and $\mathrm{SD}=13.55$ with the lowest value of the leadership style variable is 27 and the highest is 75 . The work motivation variable has a mean $=186.63$ and $\mathrm{SD}=38.40$. The variable job satisfaction has a mean= 15.77 and $\mathrm{SD}=5.83$. The employee performance variable has a mean $=27.93$ and $\mathrm{SD}=7.27$.

\section{Table 5. Bivariate Analysis}

\begin{tabular}{|c|c|c|c|c|c|c|c|c|}
\hline \multirow{3}{*}{ Variable Group } & \multicolumn{4}{|c|}{ Employee Performance } & \multirow{2}{*}{\multicolumn{2}{|c|}{ Total }} & \multirow{3}{*}{ OR } & \multirow{3}{*}{$\mathbf{p}$} \\
\hline & \multicolumn{2}{|c|}{ Lacking } & \multicolumn{2}{|c|}{ Good } & & & & \\
\hline & $\mathbf{n}$ & $\%$ & $\mathbf{N}$ & $\%$ & $\mathbf{N}$ & $\%$ & & \\
\hline \multicolumn{9}{|l|}{ Leadership Style } \\
\hline Lacking & 27 & 44.8 & 22 & 55.2 & 49 & 100 & 11.12 & $<0.001$ \\
\hline Good & 15 & 9.9 & 136 & 90.1 & 151 & 100 & & \\
\hline \multicolumn{9}{|l|}{ Working Motivation } \\
\hline Low & 19 & 43.1 & 25 & 56.9 & 44 & 100 & 4.39 & $<0.001$ \\
\hline High & 23 & 14.7 & 133 & 85.3 & 156 & 100 & & \\
\hline \multicolumn{9}{|l|}{ Working Satisfaction } \\
\hline Less satisfied & 22 & 41.5 & 31 & 58.5 & 53 & 100 & 4.50 & $<0.001$ \\
\hline Satisfied & 20 & 13.6 & 127 & 86.4 & 147 & 100 & & \\
\hline \multicolumn{9}{|l|}{ Education } \\
\hline$<$ DIII & 23 & 45.0 & 28 & 65.0 & 51 & 100 & 5.62 & $<0.001$ \\
\hline$\geq$ DIII & 19 & 12.7 & 130 & 87.3 & 149 & 100 & & \\
\hline \multicolumn{9}{|l|}{ Treatment Status } \\
\hline Non Hospitalization & 24 & 44.4 & 30 & 55.6 & 54 & 100 & 5.68 & $<0.001$ \\
\hline Hospitalization & 18 & 12.3 & 128 & $87 \cdot 3$ & 146 & 100 & & \\
\hline \multicolumn{9}{|l|}{ Employee Status } \\
\hline Intern & 17 & 54.8 & 14 & 45.2 & 31 & 100 & 6.99 & $<0.001$ \\
\hline Non Civil Servant & 25 & 14.7 & 144 & 85.3 & 169 & 100 & & \\
\hline \multicolumn{9}{|l|}{ Lama Kerja } \\
\hline$<3$ years & 18 & 40.9 & 26 & 59.1 & 44 & 100 & 3.80 & $>0.001$ \\
\hline$\geq 3$ years & 24 & $15 \cdot 3$ & 132 & 84.7 & 156 & 100 & & \\
\hline
\end{tabular}

Table 5 shows the results of the chi-square test of the influence of the leadership style of the head of the puskesmas and work motivation on employee performance as follows:

\section{a. The influence of the leadership style of the head of the puskesmas on employee performance}

The influence of a poor leadership style increases the possibility of under performance in employees. Employees with a per-
Table 4 shows that most of the study subjects $\geq$ DIII education were 149 (74.5\%), inpatient treatment status was 147 (73.0\%), public employment was 169 (84.5\%), tenure 3 years (78.0\%).

\section{Data Analysis}

Statistical analysis was used to see the effect of a dependent variable (employee performance) on the independent variable (the influence of the leadership style of the head of the puskesmas and work motivation) in table 5 . 
Indriastuti et al./ Leadership Style and Motivation Influence the Work Performance

employee performance as much as 4.39 times than employees with high work motivation $(\mathrm{OR}=4.39, \mathrm{p}<0.001)$.

\section{c. The effect of job satisfaction on employee performance}

The effect of unsatisfied job satisfaction increases the possibility of under performance in employees. Employees with less job satisfaction increase the likelihood of poor employee performance as much as 4.50 times than employees with high job satisfaction $(\mathrm{OR}=4.50, \mathrm{p}<0.001)$.

\section{d. The influence of education on employee performance}

The influence of low education increases the likelihood of underperformance in employees. Employees with low education increase the likelihood of poor performance by 5.62 times than employees with high education $(\mathrm{OR}=5.62, \mathrm{p}<0.001)$.

\section{e. Effect of treatment status on} employee performance

The effect of non-hospitalized care status increases the possibility of underperformance in employees. Employees with noninpatient treatment increase the possibility of poor performance by 5.68 times than employees with inpatient treatment status $(\mathrm{OR}=5.68, \mathrm{p}<0.001)$.

\section{f. The influence of employee status on employee performance}

The effect of intern status increases the likelihood of underperformance in employees. Employees with apprenticeship status increase the likelihood of poor employee performance by 6.99 times than employees with PTT/PNS employee status $(\mathrm{OR}=6.99, \mathrm{p}<0.001)$.

g. The effect of working time on employee performance

The effect of working length $<3$ years increases the possibility of a lack of performance in employees. Employees with $<3$ years of service increased the possibility of poor performance by 3.80 times than employees with 3 years of service $(\mathrm{OR}=$ $3.80, \mathrm{p}<0.001$ ).

\section{MultivariateAnalysis}

Multilevel multiple logistic regression analysis explains the influence of more than one independent variable and the variable at level 2 is puskesmas. The results of the analysis can be seen from Table 6 .

a. The influence of the leadership style of the head of the puskesmas on employee performance

There is a positive influence of the leadership style of the head of the puskesmas on the performance of the puskesmas employees. The good leadership style of the head of the puskesmas increased the performance of the puskesmas staff with a logodd of 2.59 units than the poor leadership style and was statistically significant $(b=3.58 ; 95 \% \mathrm{CI}=1.11$ to $3.80 ; \mathrm{p}<0.001)$.

\section{b. The effect of work motivation on employee performance}

There is a positive effect of work motivation on the performance of puskesmas employees. Work motivation increased the performance of puskesmas employees with logodd by 2.46 units than employees who were less motivated and statistically significant $(b=3.12 ; 95 \% \mathrm{CI}=0.83$ to $3.65 ; \mathrm{p}=$ $0.002)$.

c. The effect of job satisfaction on employee performance

There is a positive effect of job satisfaction on the performance of puskesmas employees. High job satisfaction increased the performance of puskesmas employees with logodd by 2.59 units than low job satisfaction and was statistically significant $(b=2.89 ; 95 \% \mathrm{CI}=0.67$ to $3.53 ; \mathrm{p}=0.004)$.

\section{d. The influence of education on employee performance}

There is a positive effect of education level on the performance of puskesmas employees. Education level D3 improved the performance of puskesmas employees 
with logodd by 2.45 units than education level $<$ D3 and was statistically significant $(b=2.89 ; 95 \% \mathrm{CI}=0.60$ to $3.13 ; \mathrm{p}=0.004)$.

e. The effect of treatment status on employee performance

There is a positive influence on the health center inpatient status on the performance

Table 6. The results of multilevel multiple logistic regression analysis of the influences of the leadership style and work motivation on employee performance

\begin{tabular}{|c|c|c|c|c|}
\hline \multirow{2}{*}{ Independent Variable } & \multirow{2}{*}{ b } & \multicolumn{2}{|c|}{ 95\% CI } & \multirow[b]{2}{*}{$\mathbf{p}$} \\
\hline & & Lower Limit & Upper Limit & \\
\hline \multicolumn{5}{|l|}{ Fixed Effect } \\
\hline Leadership Style (good) & 3.58 & 1.11 & 3.80 & $<0.001$ \\
\hline Work Motivation (high) & 3.12 & 0.83 & 3.65 & 0.002 \\
\hline Job Satisfaction (satisfied) & 2.89 & 0.67 & 3.53 & 0.004 \\
\hline Education ( $\geq$ DIII) & 2.89 & 0.60 & 3.13 & 0.004 \\
\hline Treatment Status (hospitalized) & 2.66 & 0.47 & 3.12 & 0.008 \\
\hline Employee Status (nakes) & 3.68 & 1.46 & 4.80 & $<0.001$ \\
\hline Length of Service ( $\geq 3$ years) & 2.07 & 0.07 & 2.76 & 0.038 \\
\hline \multicolumn{5}{|l|}{ Random effect } \\
\hline \multicolumn{5}{|l|}{ Variable of Health Center } \\
\hline \multicolumn{5}{|l|}{$\mathrm{N}$ observation $=200$} \\
\hline \multicolumn{5}{|l|}{$\mathrm{N}$ group $=25$} \\
\hline \multicolumn{5}{|l|}{ Average group $=8, \min =8, \max =8$} \\
\hline \multicolumn{5}{|l|}{ Log likelihood= -45.03} \\
\hline \multicolumn{5}{|l|}{$\mathrm{P}<0.001$} \\
\hline \multicolumn{5}{|l|}{$\mathrm{p}$ LR test vs logistic regression $=0.274$} \\
\hline $\mathrm{ICC}=11.75 \%$ & & & & \\
\hline
\end{tabular}

\section{f. The influence of employee status on employee performance}

There is a positive influence of employment status on the performance of health center personnel. Employment status of civil servant decreased health center personnel performance with logodd by 3.14 units compared to interns employment status (b $=3.14 ; 95 \% \mathrm{CI}=1.69$ to $7.34 ; \mathrm{p}=0.002$ ).

g. The effect of working time on employee performance

There is a positive effect of length of service on the performance of health center personnel. The length of service 3 years increased the health center personnel performance with logodd of 1.97 units than the length of service $<3$ years $(b=2.07 ; 95 \%$ $\mathrm{CI}=0.78$ to $2.76 ; \mathrm{p}=0.038$ ). of puskesmas employees. The status of health centers with inpatients decreased the performance of puskesmas employees with logodd by 2.59 units than those of puskesmas with non-hospitalization and was statistically significant $(b=3.68 ; 95 \%$ $\mathrm{CI}=1.46$ to $4.80 ; \mathrm{p}<0.001$ ). h. The influence of health center on the performance of puskesmas employees

There was a contextual effect of health center on the health personnel performance $(\mathrm{ICC}=11.75 \%)$. Variations in performance of employees as much as $42.12 \%$ are influenced by health centers.

\section{DISCUSSION}

1. The influence of the head of health center leadership style on employee performance

The results of this study indicate that there is a positive influence of the leadership style of the head of the puskesmas on the performance of the puskesmas employees. The good leadership style of the head of the puskesmas increased the performance of 
the puskesmas staff with a logodd of 2.59 units than the leadership style which was not good and statistically significant $(b=$ 2.59; $95 \% \mathrm{CI}=0.69$ to $4.96 ; \mathrm{p}=0.010$ ).

This study is in line with Marzuki et al., (2019) which states that leadership style affects the performance of puskesmas. That means that the leader can provide encouragement and enthusiasm for subordinates, which has a big impact in providing services to the community. Work planning affects the performance of the puskesmas where work planning on the performance of the puskesmas is very detailed because it has an annual work program that involves staff/groups in preparing quality programs. In addition, the health program implemented by the puskesmas has an influence on the performance of the puskesmas through a dominant leadership style approach.

\section{The Influence of Work Motivation on Employee Performance}

The results of this study indicate that there is a positive effect of work motivation on the performance of puskesmas employees. Work motivation increased the performance of puskesmas employees with logodd by 2.46 units than employees who were less motivated and statistically significant $(b=$ 2.46; $95 \% \mathrm{CI}=0.59$ to $5.10 ; \mathrm{p}=0.014$ ).

This study is in line with Rahmadani et al., (2019) which states that motivation has an influence on the performance of midwives and is statistically significant. Midwives who have high motivation perform better than midwives with low motivation. Higher motivation in doing a job or anything can increase better performance. It can be assumed that midwives with strong motivation tend to provide health services (Wahidah et al., 2018).

According to Abidin (2020), motivation can improve employee performance. Motivation is an encouragement to a series of processes of human behavior in achieving goals while the elements contained in motivation include elements of generating, directing, maintaining, showing intensity, being continuous and having a purpose. Motivation affects performance, although it is not the only factor that shapes performance. Individual input and work context are two key factors that influence motivation. Workers have abilities, work knowledge, dispositions and traits, emotions, moods, beliefs and values at work. The work context includes the physical environment, task completion, organizational approach to recognition and reward, adequacy of supervisory and coaching support, and organizational culture (Wibowo, 2016).

\section{The Effect of Job Satisfaction on Employee Performance}

The results of this study indicate that there is a positive effect of job satisfaction on the performance of puskesmas employees. High job satisfaction increased the performance of puskesmas employees with logodd by 2.59 units than less job satisfaction and was statistically significant ( $\mathrm{b}=$ 2.59; $95 \% \mathrm{CI}=0.44$ to $4.23 ; \mathrm{p}=0.016$ ).

This study is in line with Indrawati et al., (2013) which states that employee job satisfaction will be able to improve their performance and be able to improve their performance. The implementation of a good compensation and career system, a conducive work environment, a good relationship between co-workers and superiors will trigger employee job satisfaction, so that their technical and interpersonal skills become good as well. If there is an increase in technical and interpersonal skills, it indicates an increase in performance,

Ezeanyim et al., (2019) shows the results that job satisfaction has an influence on the performance of an employee. Job satisfaction is an emotional attitude that is 
pleasant and loves one's work. Job satisfaction in work is job satisfaction enjoyed in work by obtaining work results, placement, treatment, equipment and a good working environment. Job satisfaction will be achieved if the needs of employees are met through work in which job satisfaction is a happy emotional state or positive emotion that comes from the assessment of one's work or experience. High job satisfaction will improve employee performance towards the organization where they work (Damayanti et al., 2018).

\section{The effect of education on employee performance}

The results of this study indicate that there is a positive effect of the level of education on the performance of puskesmas employees. Education level D3 increased the performance of puskesmas employees with logodd by 2.45 units than education level $<\mathrm{D} 3$ but statistically significant $(\mathrm{b}=2.45$; 95\% $\mathrm{CI}=0.46$ to $4.23 ; \mathrm{p}=0.014$ ).

This study is in line with Dewi et al., (2016) which states that there is a positive effect of education level on employee performance and statistically significant. A high level of education or more improve employee performance than those with a low level of education. Education level is one of the factors that can be directly or indirectly related to employee performance. If the level of education applied by company leaders to employees is right, then employee performance will be maximized, and vice versa (Reza et al., 2017).

Education level is the level obtained by a person starting from elementary school to college level. The level of education is needed by an employee, because it will be able to bring a good influence on himself and the organization where he works. The level of education will also have a strong influence on the performance of employees to carry out and complete well- defined work, because with adequate education the knowledge and skills of these employees will be wider and able to solve the problems faced (Putra et al., 2016).

\section{The Effect of Care Status on Employee Performance}

The results of this study indicate that there is a positive influence of the inpatient status of the puskesmas on the performance of the puskesmas employees. The status of health centers with inpatients decreased the performance of puskesmas employees with logodd by 2.59 units than the status of puskesmas with non-hospitalization and was statistically significant $(b=2.59 ; 95 \%$ $\mathrm{CI}=0.65$ to $5.10 ; \mathrm{p}=0.015$ ).

This study is in line with Marwandi et al., (2020) which states that there is an effect of the inpatient status of the puskesmas on the performance of the puskesmas employees. The status of health centers with inpatients lowers the performance of puskesmas employees with logodd by 2.97 units than the status of puskesmas with non-hospitalization. There are differences in the performance of health services, both between inpatient and outpatient or noninpatient Puskesmas. This is possible when all the factors that support improving the performance of both individuals, organizations and management are not carried out optimally (Rotty, 2016).

Work facilities are a supporting factor for achieving goals such as in inpatient and non-inpatient facilities at the puskesmas. Without work facilities, specific job tasks cannot be performed and objectives cannot be accomplished as they should be. The number of quality and quantity should receive priority attention from the leader. Efforts to maintain quality are a leadership strategy to maintain (preventive action). The provision of work facilities and infrastructure is one that needs to be considered properly, because without the facilities, the 
work carried out will be constrained, as well as decreased employee morale (Sianturi and Hartono, 2019).

\section{The Influence of Employee Status on Employee Performance}

The results of this study indicate that there is a positive effect of PNS/PTT employee status on the performance of puskesmas employees. PNS/PTT status of puskesmas employees decreased the performance of puskesmas employees with logodd by 3.14 units than the status of interns and was statistically significant $(\mathrm{b}=3.14 ; 95 \% \mathrm{CI}=$ 1.69 to $7.34 ; \mathrm{p}=0.002$ ).

This study is in line with Hendrajana et al., (2017) which states that the higher the difference in employment status, the employee's performance will decrease. Employee status has a positive effect on employee performance. An employee is someone who works in an organizational unit, a business entity, both governmentowned and private, whether as a permanent employee or not, who is given work benefits in accordance with applicable laws and regulations, to carry out a job in a position determined by the employer and all of this is done to meet needs (Ola et al., 2019).

Employee performance is influenced by several factors, one of which is employment status. Employment status can be interpreted where status is a state or position (person, body, and so on) in the relationship around them, while staffing is related to employees. So that employment status can be interpreted as the position of people who work in a company or government. Employment status can increase or decrease the level of performance of employees (Anjarnako and Kurlilah, 2020).

\section{The Effect of Working Length on Employee Performance}

The results of this study indicate that there is a positive effect of length of work on the performance of puskesmas employees, but it is not significant. Public health center staff working years 3 years increased the performance of puskesmas employees with a logodd of 1.97 units than employees working years $<3$ years and was statistically significant $(b=1.97 ; 95 \% C I=0.01$ to 4.14 ; $\mathrm{p}=0.048$ ).

This study is in line with Rahmadani et al., (2019) which states that tenure has an influence on the performance of midwives and is statistically important. Midwives with $>13$ years of service tend to have better performance than midwives with $<13$ years of service.

The length of a person's work can increase a person's work experience. Work experience is the most influencing factor in creating the growth of a business. The higher the experience possessed by the workers will lead to the high growth of the business. From the results of research on work experience there is a positive influence on work productivity either partially or simultaneously (Sulaeman, 2014).

Besides being able to increase one's work experience, length of work can also deepen and broaden work abilities. The more often a person does the same job, the more skilled he is and the faster he gets the job done. The more kinds of work a person does, the richer and wider his work experience is, and allows for increased performance (Gusnetti, 2014).

\section{The Influence of Public Health} Centers on the Performance of Health Center Employeess

The results of this study indicate that there is a contextual effect on the performance of puskesmas employees ( ICC $=42.12 \%$ ). Variations in performance of employees as much as $42.12 \%$ are influenced by the puskesmas. Table 4.4 shows that the ICC value in this study is greater than the rule of thumb benchmark of $8-10 \%$, so the con- 
textual influence which in this study is the puskesmas is very important to note.

The Community Health Center (Puskesmas) is one of the most important public health service facilities in Indonesia. The Puskesmas is the technical implementing unit of the district/city service that is responsible for carrying out health development in a work area (Ekasari et al., 2017 cit MOH, 2011).

The Puskesmas was established to provide basic, comprehensive, complete, and integrated health services for all residents living in the working area of the Puskesmas. Health programs and efforts organized by the Puskesmas are the main programs (public health essentials) that must be implemented by the Government to realize the welfare of the community. Currently, puskesmas have been established in almost all corners of the country. To reach all of its working areas, the Puskesmas is strengthened by supporting Puskesmas and Mobile Health Centers. Except that for areas that are far from referral service facilities, puskesmas are equipped with inpatient facilities (Sulaeman, 2014).

This study is in line with Marwandi et al., (2020) which states that health centers have an influence on employee performance. Puskesmas with puskesmas accreditation status Madya improves the performance of puskesmas employees with logodd by 3.01 units than accreditation status < Intermediate. Puskesmas accreditation is an acknowledgment of puskesmas that is given by an independent institution that administers accreditation which is determined by the Minister after it is assessed that the Puskesmas has met the Puskesmas service standards set by the Minister to improve the quality of Puskesmas services on an ongoing basis (Kemenkes RI, 2014).
Based on the results of the study, it can be concluded that there is a significant influence between leadership style, work motivation, job satisfaction, education, employment status, and tenure on performance of puskesmas employees. Variations at the puskesmas level show that there is a contextual effect on the performance of puskesmas employees.

\section{AUTHOR CONTRIBUTION}

Latty Indriastuti acts as the main researcher and acts as the main researcher who plays a role in coordinating research, conducting all stages of research, and completing research manuscripts. Endang Sutisna Sulaeman played a role in preparing the research framework, processing research data, presenting the results of research analysis, and preparing research manuscripts. Soemanto and Eti Poncorini Pamungkasari played a role in developing research ideas, research designs, and research hypotheses.

\section{CONFLICT OF INTEREST}

There is no conflict of interest in this study.

FUNDING AND SPONSORSHIP

This study is self-funded.

\section{ACKNOWLEDGMENT}

We would like to thank all the heads of puskesmas and puskesmas staff in Ciamis Regency who have assisted in the research and students who have been willing to become research subjects.

\section{REFERENCE}

Abidin AZ (2020). Analysis of the effect of work motivation on nurse performance at Puskesmas. Economics and Education Journal. 2(2). https://doi.org/10.33503/ecoducation.v2i2.847.

Anjarnako TS, Kurlilah A (2020). Pengaruh status kepegawaian, kompetensi kar- 
Indriastuti et al./ Leadership Style and Motivation Influence the Work Performance

yawan dan budaya organisasi terhadap kinerja karyawan di gudang PT. Mitra Pinasthika Mulia Sidoarjo (The influence of employment status, employee competence and organizational culture on employee performance at PT. Mitra Pinasthika Mulia Sidoarjo). https://unsuri.ac.id/wp-content/uploads/2020/01/4.-Tri-Seno.pdf.

Azis MA (2016). Pengaruh motivasi kerja, disiplin kerja dan lingkungan kerja terhadap kinerja melalui kepuasan kerja pada pegawai puskesmas Kecamatan Balapulang Kabupaten Tegal (The influence of work motivation, work discipline and work environment on performance through job satisfaction on public health center employees, Balapulang District, Tegal Regency). Multiplier, 1(1): 99-198.

Damayanti R, Hanafi A, Cahyadi A (2018). Pengaruh kepuasan kerja terhadap kinerja karyawan (Studi kasus karyawan non medis RS Islam Siti Khadijah Palembang) (The effect of job satisfaction on employee performance (Case study of non-medical employees of Siti Khadijah Islamic Hospital Palembang). Jurnal Ilmiah Manajemen Bisnis Dan Terapan. 15(2): $75^{-}$ 86. https://doi.org/10.29259/jmbt.v$15 \mathrm{i} 2.6655$.

Dewi DKR, Suwendra IW, Yulianthini NN (2016). Pengaruh tingkat pendidikan dan motivasi kerja terhadap kinerja karyawan (The effect of education level and work motivation on employee performance). Jurusan Manajemen.

Ekasari R, Pradana S, Adriansyah G, Prasnowo MA, Rodli MF, Hidayat $\mathrm{K}$ (2017). Analisis kualitas pelayanan puskesmas dengan metode ServQual (Analysis of health center service qua- lity with the ServQual method). Jurnal Darussalam. 9(1): 86-93. https://doi.org/10.30739/darussalam.v9i1. 118.

Ezeanyim, Ezinwa E, Ufoaroh, Theresas E, Ajakpo (2019). The impact of job satisfaction on employee performance in selected public enterprise in Awka, Anambra State. Global J Manage Business Res: A Administration and Management. 19(7). https://journalofbusiness.org/index.php/GJMBR/ar ticle/view/2791.

Gusnetti (2014). Faktor-faktor yang mempengaruhi kinerja karyawan pada PT. Garuda Indonesia Pekanbaru (The factors that affect the performance of employees at PT. Garuda Indonesia Pekanbaru). Journal FISIP Universitas Riau. 1(2): 1-11. https://jom.unri.ac.id/index.php/JOMFSIP/index.

Hendrajana IGMR, Sintaasih DK, Saroyani $P$ (2017). Analisis hubungan status kepegawaian, komitmen organisasional, dan kinerja karyawan (Analysis of the relationship between employment status, organizational commitment, and employee performance). E-Jurnal Ekonomi Dan Bisnis Universitas Udayana. 1: 357-384.

Indrawati $\mathrm{AD}$ (2013). Pengaruh kepuasan kerja terhadap kinerja karyawan dan kepuasan pelanggan pada rumah sakit swasta di Kota Denpasar (The effect of job satisfaction on employee performance and customer satisfaction at a private hospital in Denpasar City). Jurnal Manajemen, Strategi Bisnis, dan Kewirausahaan. 7(2).

Kemenkes RI (2014). Rencana pengembangan tenaga kesehatan tahun 2011 - 2025 (Health Personnel Development Plan 2011 - 2025). Kemenkes RI. www.who.int/workforcealliance/- 
Indriastuti et al./ Leadership Style and Motivation Influence the Work Performance

countries/inidonesia_hrhplan_2011_ 2025.pdf.

Marzuki F, Mardiyanto H, Sugiarti DY (2018). The effect of leadership style and work planning on puskesmas performance. Jurnal Visipena. 9(2): 316-329. https://doi.org/10.46244/visipena.v9i2.462.

Marwandi D, Sulaeman ES, Pawito (2020). Effect of leadership style of the head of the community health center and other determinants on the health personnel performance in Boyolali, Central Java. J Health Policy Manage. 5(1): 74-84. https://doi.org/10.26911/thejhpm.2020.05.01.07.

Mathis R, Jackson W (2006). Human Resources Development (Track MBA series/terjemahan). Jakarta: Prestasi Pustaka.

Ola AB, Abdullah R, Azis M (2019). Research result the influence of staffing status and organizational commitment on performance through job satisfaction at UPTD Puskesmas Kajuara in Bone Regency. J Manage. 2(1). https://journal.stieamkop.ac.id/index.php/yume.

Putra IWI, Suwendra IW, Bagia IW (2016). Pengaruh tingkat pendidikan dan disiplin kerja terhadap kinerja karyawan (The influence of education level and work discipline on employee performance). E-Journal Bisma Universitas Pendidikan Ganesha. 4(1). https://ejournal.undiksha.ac.id.

Rahmadani LN, Budihastuti UR, Pamungkasari EP (2019). Does health center have contextual effect on midwife performance? Multilevel analysis evidence from East Kalimantan, Indonesia. J Health Policy Manage. 4(3): 150-160. https://doi.org/10.26911/thejhpm.2019.04.03.0.
Reza WP, Marzolina, Muafar TF (2017). Pengaruh tingkat pendidikan, pengalaman kerja dan penempatan terhadap kinerja karyawan pada PT. Bank Riau Kepri Cabang Teluk Kuantan (The effect of education level, work experience and placement on employee performance at PT. Bank Riau Kepri Teluk Kuantan Branch). JOM Fekon. 4(1): 426-431. https://media.neliti.com/media/publications /129783-ID-pengaruh-tingkat-pendidikan-pengalaman-k.pdf.

Rustilah S (2018). Pengaruh gaya kepemimpinan dan kompensasi terhadap kepuasan kerja dan kinerja pegawai tenaga kontrak (The effect of leadership style and compensation on job satisfaction and performance of contract employees). J Manage. 2(2): 219-222. http://dx.doi.org/10.25157/jmr.v2i2.1798.

Rotty SJL (2016). Health care services comparison between community health center equipped with in patient ward and out patient department in North Minahasa. Jurnal EMBA. 4(2): 311322.

Salbiah S, Mahardika BW (2017). Pengaruh motivasi kerja terhadap kinerja tenaga kependidikan Universitas Muhammadiyah Surabaya Tahun 2016 (The influence of work motivation on the performance of education personnel at the University of Muhammadiyah Surabaya in 2016). Jurnal Balance, 14(2): 83-105. http://dx.doi.org/10.30651/blc.v14io2.1280.

Siagian SP (2008). Teori dan praktek kepemimpinan (Leadership theory and practice). Jakarta : Rineka Cipta.

Sulaeman A (2014). Pengaruh upah dan pengalaman kerja terhadap produktivitas karyawan kerajinan ukiran Kabupaten Subang (The effect of wages 
and work experience on productivity of carving craft employees in Subang Regency). Trikonomika, 13(1): 91100.

Sari EK, Minarsih MM, Gagah E (2016). Analisis pengaruh gaya kepemimpinan, motivasi, kualitas kehidupan kerja terhadap kinerja karyawan (Studi kasus pada PD. BKK Dempet Kabupaten Demak) (Analysis of the influence of leadership style, motivation, quality of work life on employee performance (Case Study at PD. BKK Dempet Demak Regency). Journal of Management, 2(2): 1-6.

Sulistiyani AT (2008). Kepemimpinan profesional: Pendekatan leadership games (Professional leadership: Leadership games approach). Yogyakarta: Penerbit Gava Media.

Sianturi RS, Hartono (2019).Factor that influence the performance of pegawai prospects of Rantang Medan Petisah. Jurnal Kesehatan Global. 2(3): 150157. http://ejournal.helvetia.ac.id/index.php/jkg.

Wahidah N, Sulaeman ES, Budihastuti UR (2018). Determinants of midwife performance in lactation management in Surakarta and Karanganyar, Central
Java. J Health Policy Manage. 3(1): 26-33. https://doi.org/10.26911/thejhpm.2018.03.01.04.

Wahyuni E (2015). Pengaruh budaya organisasi dan gaya kepemimpinan terhadap kinerja pegawai bagian keuangan organisasi sektor publik dengan motivasi kerja sebagai variable intervening (The influence of organizational culture and leadership style on employee performance in the financial department of public sector organizations with work motivation as an intervening variable). Jurnal Nominal. 4(1): 97-112. https://doi.org/10.21831/nominal.v4i1.6890.

Wibowo (2016). Manajemen Kinerja (Work management). Jakarta: Rajawali Press.

Wibowo AT, Margono SA (2018). Pengaruh pengembangan sumber daya manusia, fasilitas kantor, dan budaya organisasi terhadap kinerja pegawai pada Puskesmas Umbulharjo I Kota Yogyakarta (The influence of human resource development, office facilities, and organizational culture on employee performance at the Umbulharjo I Public Health Center, Yogyakarta City). http://etd.repository.ugm.ac.id/. 